\title{
The Politics of Libraries and Librarianship: Challenges and realities
}

\section{EDITED BY}

\section{KERRY SMITH}

\section{Chandos Publishing}

Oxford $\cdot$ England

Chandos Publishing (Oxford) Limited

TBAC Business Centre

Avenue 4

Station Lane

Witney

Oxford OX28 4BN

UK

Tel: +44 (0) 1993848726 Fax: +44 (0) 1865884448

E-mail: info@chandospublishing.com

www.chandospublishing.com

First published in Great Britain in 2009

ISBN:

9781843343431 (paperback)

9781843343448 (hardback)

1843343436 (paperback)

1843343444 (hardback)

(C) The contributors, 2009

British Library Cataloguing-in-Publication Data.

A catalogue record for this book is available from the British Library.

All rights reserved. No part of this publication may be reproduced, stored in or introduced into a retrieval system, or transmitted, in any form, or by any means (electronic, mechanical, photocopying, recording or otherwise) without the prior written permission of the Publishers. This publication may not be lent, resold, hired out or otherwise disposed of by way of trade in any form of binding or cover other than that in which it is published without the prior consent of the Publishers. Any person who does any unauthorised act in relation to this publication may be liable to criminal prosecution and civil claims for damages.

The Publishers make no representation, express or implied, with regard to the accuracy of the information contained in this publication and cannot accept any legal responsibility or liability for any errors or omissions.

The material contained in this publication constitutes general guidelines only and does not represent to be advice on any particular matter. No reader or purchaser should act on the basis of material contained in this publication without first taking professional advice appropriate to their particular circumstances. Any screenshots in this publication are the copyright of the website owner(s), unless indicated otherwise.

Typeset by Domex e-Data Pvt.Ltd.

Printed in the UK and USA.

\section{Contents}

List of figures $x i$

List of contributors xiii

List of acronyms xix

Foreword xxiii

Preface $x$ xix

Part I: An international political framework for libraries 1

1 An international political framework for libraries 3

Alex Byrne

An issue for libraries 4

Civil society 5

The place of libraries 7

An information society 8

Libraries in the information society 9

Library ethos 13 
Seeking political influence 14

An international political framework for libraries 16

References 18

2 Intellectual property - benefit or burden for Africa? 19

Denise Nicholson

Introduction 19

What is intellectual property? 19

Intellectual property situation in Africa 20

Importance of access to information 20

Copyright - a barrier for education and libraries 21

Where is the balance? 24

$\mathrm{v}$

Copyright - benefit or burden? 25

International pressures 26

African Growth Opportunity Act - stepping-stone to a free

trade agreement? 28

What is a free trade agreement? 29

Harmonisation versus competition 30

Impact of TRIPS-Plus on African countries 32

Anti-circumvention technologies 33

TRIPS-Plus and public health 34

Should Africa adopt TRIPS-Plus? 35

Copyright cooperation in Africa 36

Challenges and recommendations 37

Acknowledgements 38

Notes 38

References 39

3 The $\mathrm{Cl}$ study on copyright and access to knowledge 43

Rajeswari Kanniah

Introduction 43

The international copyright regime 44

National copyright laws 46

WIPO's legislative advice 47

The US-Singapore Free Trade Agreement 49

Pricing of copyrighted materials 49

Using copyright laws to increase access to knowledge 50

Conclusion 51

Note 52

References 52

Part II: Politics and funding for libraries: some international examples 53

4 Political realities and the English public library service 55

Chris Batt

vi

The Politics of Libraries and Librarianship

Introduction 55

The historical perspective: popularity, invisibility and good fortune 56

The 'outside world' 59

And the consequence is...? 61

Conclusions 68

Notes 70

References 70

5 Public library development in New South Wales 71

David J. Jones

Good in parts: libraries in nineteenth-century New South Wales 71

The Free Public Library, Sydney 72

The Municipalities Act 73

A mixed bag 73

Steady as she goes: the early twentieth century 74

Schools of arts examined 75

The Munn-Pitt Report 75

The Free Library Movement 76

The Libraries Advisory Committee 77

Deciding on subsidies 78

The Library Act 78

The Act takes hold 79

Acknowledgements 80

References 80 
6 Libraries in the South Pacific 81

Paula $H$. Jones

Libraries in the region 83

Libraries in the doldrums 84

Library training in the region 86

Levels of staffing in South Pacific libraries 87

Library associations 87

vii

Contents

Regional efforts to improve libraries 88

USP Library 89

Standing Conference of Pacific Libraries (SCOPAL) 89

Pacific Information Centre (PIC) 90

Pacific Regional Initiatives for the Delivery of Basic Education (PRIDE) 91

CLAIM 91

Mechanisms for change - national planning documents 92

Aid and libraries in the South Pacific 95

Cyclones, coups and corruption 96

Solutions to library development 97

Notes 98

References 98

Further reading 99

7 Staying alive in a political world: the case of libraries and

information centres in Nigeria 101

Zakari Mohammed and Victoria Okojie

Introduction 101

The library and the political class 102

The turning point between the library and the political class 104

Staying alive 108

References 115

8 Libraries and politics - Danish reflections and examples 117

Winnie Vitzansky

Introduction 117

Our political environment 117

Do today's library associations need to be politically aware? 118

Bringing the libraries into the political agenda 119

Lobbying for libraries - a Danish perspective 121

Library strategies 121

Partnerships 123

viii

The Politics of Libraries and Librarianship

International cooperation 125

Conclusion 127

Note 127

9 The political framework for public libraries in the Netherlands 129

Marian Koren

The library landscape and politics 129

Development and legislation 130

Bibliotheekvernieuwing: restructuring and innovation 131

Political perceptions: a research project 134

Political awareness-raising 138

Working with stakeholders 139

Leadership with a background in politics 141

Notes 143

References 144

Further reading 144

Key organisations and websites 145

Part III: Library education 147

10 A unified approach to the teaching of library studies 149

Michael Gorman

Introduction 149

Education in library studies 150

The field of library studies 151

The curriculum 155

The faculty 156

Summary 157

Acknowledgements 157 
References 157

11 Is library course accreditation a political necessity? 159

Kerry Smith

Introduction 159

ix

Contents

Educational programmes in librarianship 159

What is accreditation? 161

Why accredit? 162

Accredit or recognise? 163

Is accreditation a political process? 165

LIS university education in Australia 167

Is there a role for research in LIS professional education? 169

What is accreditation worth? 171

Conclusion 172

Acknowledgements 173

Notes 173

References 174

Further reading 175

Index 177

159

The Politics of Libraries and Librarianship

Is library course accreditation a political necessity?

Kerry Smith

Introduction

This chapter is not solely about the processes and politics of the accreditation situation as they apply in Australia, although much of the discussion is based on Australian experiences. Libraries are a global phenomenon and offer a sustainable information service to the many communities they serve. In order to prepare people to work in these libraries, educational programmes in librarianship are offered in many countries. These programmes vary in the training and education they offer. One way of monitoring and managing this variety is for professional associations to accredit the programmes for their relevance to the profession they serve. In order for this to happen, the associations develop expectations for the content of such programmes.

\section{Educational programmes in librarianship}

Educational programmes in library studies include introductory clerical certificates that familiarise students with library operations; library technician certificate and diploma programmes which cater for technician and higher-level library assistant appointments, as recognised in many Commonwealth countries; undergraduate-level studies which enable professional qualification, again recognised in many Commonwealth countries and becoming more common in the USA; postgraduate professional qualifications at the graduate diploma level, another Commonwealth recognised qualification; master's-level 159

11

professional qualifications as available in the USA and Canada and now in a number of other countries; and research programmes at the honours, thesis master's and $\mathrm{PhD}$ levels. Like other professions, librarianship in many countries has sought recognition and/or accreditation of courses at the professional level.

The International Federation of Library Associations 'Guidelines for professional library/information educational programs' were prepared by 
the Section on Education and Training in 2000, with the last update being in 2002 (IFLA, 2000). They are currently being considered for revision. The document recognises the 'long and distinguished history' of library education, and that educational programmes are offered at the technical, graduate and professional levels, and also at research and doctoral levels. The guidelines address the graduate and professional levels and acknowledge core elements which should appear in library education programmes:

the information environment, information policy and ethics, and the history of the field;

_ information generation, communication and use;

_ assessing information needs and designing responsive services;

_ the information transfer process;

_ organisation, retrieval, preservation and conservation of information;

_ research, analysis and interpretation of information;

_ applications of information and communication technologies to

library and information products and services;

_ information resource management and knowledge management;

_ management of information agencies;

_ quantitative and qualitative evaluation of outcomes of information and library use.

The guidelines also suggest that:

the curriculum contain a practicum, internship or fieldwork that incorporates appropriate means to allow students to appreciate the interplay between professional theories and their application in professional practice;

methods of teaching include skills that can be transferred into

workplace situations, e.g. teamwork, communication;

the curriculum be regularly reviewed, and the LIS staff should have the oopportunity to offer consultancies to libraries and information agencies.

160

The Politics of Libraries and Librarianship

There is no comment in this IFLA document on accreditation or recognition processes for courses which follow these guidelines. How do we find out about these educational programmes? The World Guide to Library Archive and Information Science Education was published in 1995 by IFLA (Riss-Fang et al., 1995). It has been for the most part superseded by information located on the World Wide Web (WWW): sites include the World List of Departments and Schools of Information Studies, Information Management, Information Systems, etc. (2007) and the American Library Association's ‘Directory of accredited masters programs’ (ALA Office of Accreditation, 2007). Nevertheless, a new edition of the World Guide is imminent.

\section{What is accreditation?}

The Shorter Oxford English Dictionary (1984: 14) defines accreditation as 'furnishing with credentials; authoritatively sanctioning'. Authoritative sanctioning can come in another way. The Australian Library and Information Association (ALIA)1 prefers to 'recognise' library programmes. Recognition, according to the same dictionary, has a number of meanings. That relevant in this context is: 'the action of acknowledging as true, valid or entitled to consideration: formal acknowledgment as conveying approval or sanction of something. To recognise is to acknowledge by special notice, approval or sanction; to treat as valid, as having existence or as entitled to consideration' (ibid.: 1764).

Is there a difference between these two levels of authorisation? Since accreditation means giving credentials, this brings with it a formality in the process and implies that a person or body with the acquired and required knowledge and standing would be assessing the programme or 
person(s) against known standards, and awarding the necessary

credentials should the programme pass tests and benchmarks.

Recognition does not give credentials, rather it validates a programme or person(s) as relevant to a set of criteria against which it is assessed.

Parr (1991: 100) acknowledged a similarity between the recognition of courses by ALIA and accreditation, 'since [ALIA] assesses courses in library and information science schools against certain criteria and then admits their graduates without further examination or qualification to its professional register'. Parr (ibid.) believed that 'The real difference between accreditation and recognition in the Australian context comes down to one of authority and intention.' Perhaps these issues are minor; however, as will be revealed, the processes for each are not that dissimilar. 161

Is library course accreditation a political necessity?

\section{Why accredit?}

Like other professions, the library profession is generally keen to have its members recognised in the workplace as well prepared and educated for the tasks and challenges ahead of them. This recognition carries with it the imprimatur of the relevant profession regarding the educational programmes in which its future professionals have successfully participated. It should stimulate improvement in standards and in educational institutions and programmes (Flowers, 1979).

The development of professions received considerable impetus from the scientific and technological advances of the Second World War, when it became apparent that many areas of expertise were required in the emerging and changing workforce. These levels of specialisation are generally recognised under a general professional title, e.g. medicine, which can include physicians, urologists, oncologists, anaesthetists, obstetricians and gynaecologists. The natural sciences are even more specialised: geologists have their sub-groups of petroleum geologists, mineral geologists, petrologists, exploration geologists, geophysicists, palaeontologists, etc.; and there are the botanists, physicists and biologists, for example, who also have their sub-groups.

There is a similar complexity of professional identity in librarianship. Members of the profession can take advantage of the number of specialisations it offers: these specialisations are usually achieved in the workplace, where professionals work in certain specialities or in special types of library environments. The first category includes, for example, cataloguers and indexers, and within this category can be found those who specialise in certain types of cataloguing and indexing, e.g. music, languages, subjects and the like; those who work with rare materials; and database builders. The second category includes those who work, for example, in special, theological, geoscience, law, medical, academic, public and school libraries.

Librarians have been around for centuries. However, the academic endeavour and research scholarship of the discipline do not command the same attention from associations and professional peers as they do in many of the aforementioned professions. In the natural sciences, practice is informed by research process, academic scholarship and practical know-how. The members of the natural science academies (geoscience is one example) are still considered members of their profession even though they have moved away from general/industry practice. Nevertheless, the trend to license or accredit is evident for those professionals who practise in industry. It is the academic natural scientists who, for the most part, 162

The Politics of Libraries and Librarianship

contribute to the extensive professional literature, and their work and writings are closely followed by those in industry (Smith, 2003).

Is this the same in librarianship? There is a professional literature in library and information studies (LIS), but much of it contains reports of 
practice. Some journals demand a refereeing process, and few are recognised in academia as being of a scholarly nature.2 What of the LIS academics? Do the same patterns of membership and scholarship apply? Those LIS academics who meet the criteria for professional membership of their association(s) are able to join; and there are other categories of membership which can be used so that academics can keep in touch with professional matters. The professional interplay is, in my view, another story. It seems that just as librarians categorise their work, so too they categorise their networking and professional activity. Established groups tend to network together (e.g. the special librarians, the cataloguers, the university library community). It might be argued that so, too, do the academic community network among themselves. It also seems that in some countries a definite practitioner/educator divide exists. However, because of accreditation/recognition demands on their LIS programmes, LIS educators must also be participants in the LIS communities they serve.

\section{Accredit or recognise?}

The professional recognition or accreditation process is a considered set of events. It is generally taken very seriously by the associations that practise it, by the professionals who are members of those associations and by the academic community whose programmes are under examination. The process for library programmes is best illustrated by considering the steps involved for some of the major professional associations.

Accreditation is the preferred route of the ALA and the Chartered Institute of Library and Information Professionals (CILIP). 3 Both associations have produced comprehensive documentation for their accreditation procedures. ALIA recognises courses. An assessment of the processes and patterns of these procedures for the three associations reveals that:

there is a history of commitment by the three associations to LIS

education;

- the process is voluntary for all academic institutions;

- they all base their accreditation/recognition process on formally

adopted and rigorous procedures;

163

Is library course accreditation a political necessity?

while the three associations recognise that course design is the

prerogative of the institutions, they also set prescriptive criteria on

which course assessment by them will be based;

these course criteria are closely aligned with the IFLA guidelines for

library education programmes;

there is an important role for senior professional members of each

association in the process;

_ visits to institutions are commonly required;

- accreditation is approved by the ALA and CILIP by an accreditation

board, while in the case of ALIA the recommendations of the

recognition committee are considered by the board of directors, who

make the final judgement;

_ each association's form of accreditation varies in levels of complexity;

the ALA and ALIA generally accredit/recognise for seven years, and

$\bar{C}$ ILIP for anything up to five years;

_ administrative support is given by all associations;

_ various review strategies are employed by the three associations;

_ it appears that only the ALA levies charges to institutions for the

procedure.

When we consider the work involved in the accreditation and recognition processes, we wonder why ALIA, which undertakes almost as much work as those associations which accredit their programmes, 
does not accredit. This has been partly explained as ALIA not wanting to interfere too much in the political climate of the host universities. This issue does not prevent other professions from seeking accreditation of programmes at Australian universities.

Parr (1991) draws our attention to the differences in educational processes at the government levels between those practised in the USA and in Australia at that time, remarking that Australian universities are self-accrediting and that ALIA had no warrant, unlike the ALA, to accredit courses on behalf of state authorities. This is still the case. As Parr (ibid.: 100) states:

failure to receive recognition may be unfortunate and reflect badly on a school, but it would not prevent it from being accredited to teach and graduate students. It would only mean that graduates of its courses would not be admitted without further qualification to the professional register of the Association [ALIA].

164

The Politics of Libraries and Librarianship

At that time the Library Association (LA) in the UK approved courses, but graduates of those courses had further steps to take before being eligible to appear on the LA's professional register. This separates out academic achievement from professional training, and Parr (ibid.: 101) saw this as giving the LA control to maintain professional standards while still retaining influence among UK library schools. Parr (ibid.: 104) believed that the 'maintenance of professional standards cannot be left to schools', and argued for an even stronger approach by ALIA, since its recognition and administrative procedures were less demanding than those of the ALA and the LA.

Whether an association decides to accredit or to recognise must take into account the cost of the process. In the early days of the Library Association of Australia (LAA) course recognition process, charging institutions for the work undertaken was considered. At the time of Flowers's (1979) paper, there were views that some institutions would close their doors if they were made pay for the experience. ALIA does not levy direct charges to institutions, although there was an attempt in 2006 to do this. Feedback to ALIA from the profession and educators did not support this move and so the initiative was dropped. The costs to institutions as levied by the ALA are considerable. CILIP appears not to charge. But the costs borne by each of these associations, while variable, would be considerable.

It also appears that in North America and the UK there are some library schools that do not seek accreditation. This is not yet the case in Australia. Whether this decision is based on the cost of the process or other matters 4 needs to be borne in mind.

\section{Is accreditation a political process?}

Until recently, the professions - and there are an increasing number whose educational programmes are offered at the university level today - were recognised as without peer in their areas of expertise. Experiences of more than the library profession in some university circles have indicated a desire by some university senior managers to remove professional recognition from university processes. This desire has not been widespread, though it has contributed to a general deprofessionalisation of some courses in universities in the Western world.

When the LAA began its recognition process, library associations were held in high esteem by Australian university administrators and educators, and the associations' input to the educational process was 165 Is library course accreditation a political necessity? valued (Flowers, 1979; Parr, 1991). This may still be the case, particularly in the USA, where the ALA has a wider administrative role in accreditation than just satisfying the membership and general library 
profession on educational standards. The steady growth in library schools in Australia from the mid-1960s was followed by an increasing mix in programmes in the 1970s. Since the Dawkins higher education reforms of 1988,6 library schools have steadily declined in number around the country (Pawley et al., 2001).

There are some who work in Australian universities who appreciate the role of ALIA in the course recognition process, and there are those who appear not to. As can be deduced from earlier descriptions, considerable preparation is required by both the educators and ALIA. Some university library educators are of the view that their university has adequate processes in place to ensure the quality of its library programmes. This point was made much earlier by Foskett in 1978 (as quoted in Flowers, 1979: 318), who highlighted:

a surfeit of accreditation that some of our library schools suffer from: '...in each state there is now an accrediting body, which reviews the institution and decides whether it has the necessary facilities to teach at a tertiary level and also reviews individual courses, employing for that purpose panels drawn from the profession, and from other schools teaching in the same subject area. The present Library Association accreditation policy would seem to be a direct duplication of this procedure, and to serve very little purpose.' Although circumstances have changed since the late 1970s, such panels as mentioned by Foskett continue to exist as the universities conduct internal reviews of courses and schools, often using external reviewers. This situation is exacerbated by a higher expectation for accountability that has been placed on Australian universities by their significant funder, the federal government, with a concomitant increase in reporting requirements. The universities might then argue that the necessary checks and balances are already in place.

It also appears that library educators do not wish to be encumbered by the restrictions of the 'library' programme in their move to embrace the wider information environment and the electronic information age. Others, while going in similar educational directions, still see value in the recognition of relevant programmes by professional associations.

At Curtin University of Technology, for example, the town planning and social work programmes are two of a number which are regularly 166 The Politics of Libraries and Librarianship professionally accredited, and each area involved in these programmes works diligently to meet the established criteria for accreditation. Nevertheless, the library programme at that same university has had its challenges in the last 15 years and has at least once been threatened with closure. These events have ostensibly been because of the perceived small size of the programme when compared with other areas and disciplines7 in a university which now has a total student population of approximately 33,000. It is the view of the library studies academics involved in this and similar events that the weight of professional support and accord with relevant programmes has influenced the programme's continued existence. This support was not always evident. A major threat to close the programme occurred in the early 1990s when, although the teaching programmes were recognised by ALIA, general professional support for the school was low. The situation has improved considerably since then, but the area is constantly monitored by a university hierarchy which is necessarily driven by wider agendas.

\section{LIS university education in Australia}

Fundamental to university management issues are those of funding for Australian university education. Professional LIS education in Australia is available at the undergraduate (bachelor degree) level and the coursework postgraduate (graduate diploma or possibly master's) level. Funding for undergraduate teaching in Australian universities is supplied by the federal 
government, and students are now expected to contribute to this through a government 'loan scheme': the Higher Education Contribution Scheme (HECS). This scheme is administered through the Higher Education Funding Act 1988 and began with a modest undergraduate fee contribution (since increased considerably) in 1987 (DEST, 2007a). Before this, Australian university education at all levels was generally free (Pawley et al., 2001). The current federal government funding model means that undergraduate places in all disciplines at all Australian universities operate on a quota system. This can bring about internal political battles within universities in protecting quotas for less popular degree programmes from the grab for quotas by more popular programmes.

At the Australian postgraduate coursework level, educational programmes are now 'user pays', and today the fees can be offset by the government's FEE-HELP loans scheme which offers low interest on student loans (DEST, 2007a). As a significant number of the professional 167 Is library course accreditation a political necessity? LIS educational programmes in Australia are offered at the postgraduate level, the new FEE-HELP scheme should assist student numbers in these programmes. There was an interregnum of a few years between the demise of fully government-funded postgraduate coursework education and the introduction of precursors to the FEE-HELP scheme from 2002, and some Australian library programmes experienced a decrease in enrolments. Most programmes have picked up considerably since the introduction of these loan schemes, particularly as there is no quota for places, or the quota is set by the university or limited only by the resources available to offer the programmes. Anecdotally, university academics are wondering how long the Australian government can sustain these schemes and what will happen next.

Aligned with issues of funding are the ever-increasing number of new degree streams now being offered at Australian universities. Some LIS schools are fighting to retain their identity by offering their named programmes in flexible degree courses. Flowers (1979: 316) quotes from work by Selden in 1960: 'The issue of control over admissions is extremely important to any profession. This is especially true in the formative stages of a profession as it fights for recognition and struggles against the superior attitude of the established professions.' It could be argued that the LIS profession in a number of countries is now mature. But is it? What is the basis of a mature profession? Surely not one still struggling for recognition of its professional worth in the new information age? Surely not one with a struggling body of knowledge which is being rapidly cloned by other newer and more moderns professions?

Flowers (ibid.) takes another tack. He comments on the need to be concerned about the quality of the intake into professional courses; the need to be concerned with professional image and that a profession will be judged by the people in it. This matter has never been of concern to this author, but it is often discussed in library professional newsletters. There may be some library schools which can govern their intake. This was the case in Australia in the 1970s and 1980s, when it was possible to interview potential students before accepting them. It may be possible to do this in other countries. But as Flowers also asks, is there a danger of typecasting a profession if we do not, at best, randomly choose those who wish to enter into it? Random choice in the Australian context is based on entry scores and a preparedness to pay at the undergraduate level, and academic eligibility and the ability to pay at the postgraduate level. Yet the profession in Australia continues to attract middle-aged females in great numbers. 168 The Politics of Libraries and Librarianship 


\section{Is there a role for research in LIS professional education?}

There are other factors at play in the equation, not least of which is the need to further intellectual enquiry in matters of information studies and science; something best done at universities though severely compromised by the practice-based professional orientation of librarianship. The IFLA (2000: 2) guidelines mention 'Research, Analysis and Interpretation of Information' as a core curriculum element, and that for academic staff teaching at the professional level 'a sustained record of scholarship is expected comparable to that expected of university teachers in other disciplines' (ibid.: 3). The CILIP (2005) documentation specifically mentions a prime concern with course relevance in an applications environment providing generic and transferable skills, rather than purely academic issues. The ALA (ALA Committee on Accreditation, 2006) documentation recommends consultancies so that academics in the field stay in touch with practice. Smith and Harvey (2006) contemplated the role of professional associations in fostering a research culture among members, emphasising the Australian context. They reported evidence of some associations realising that research and the research process need to be better recognised, particularly as library professionals are increasingly undertaking higher-level qualifications which include a research component. Yet a research qualification is not always necessary for recognition as a professional librarian, so the question needs to be asked: why should librarians bother to undertake the research rigours and intellectual endeavour to achieve it? There is, for example, the clear expectation by Australian universities that any library professional hoping to enter an academic career should either possess or be well on the way to completing a PhD. Changes to the funding of university research are currently under way in Australia, with the establishment of the research quality framework (RQF) and new methods of assessing research undertaken being developed by the federal government (DEST, 2007b). If LIS professional education is to remain at the university level then the educators themselves need to consider their position in the broader Australian research agenda carefully, particularly as many universities are striving to be included as 'teaching and research' universities, if not in the 'research only' category proposed. The final category of becoming a 'teaching only' university is also possible, but not favouored by some of the remaining universities in which LIS education is currently offered.

169

Is library course accreditation a political necessity?

Former ALIA president Gillian Hallam (2005: 4), herself an LIS

educator, noted in a 'Frontline' column in inCite that:

it can be strongly argued that research is critical for the creation of professional knowledge and therefore critical to the survival and growth of the library and information profession. Without a commitment to research, we will not be a profession as such, but merely an occupation that focuses on routine processes.

LIS educators have a responsibility to ensure graduates are equipped not only with the conceptual structures and thinking processes of their discipline, but also with an understanding of and experience in the range of research methodologies that can be applied in practice.

Perhaps significantly, nowhere in her column does Hallam suggest that the professional association, ALIA, has a role in ensuring that research is firmly placed in the curriculum of first professional qualifications; rather, the responsibility lies with librarianship educators. Is there enough interest in the profession to seek recognition of research not only as a coursework subject but also as a demonstrated practice through research 
project work?

The recent establishment of a research fund capability within ALIA has meant that, in order to secure taxation concessions, ALIA needed to set up a committee of researchers to administer requests seeking to access this money. So the ALIA Research Committee was born. Interestingly, fund management is only a small part of the committee's business: its discussions range far and wide on research matters in LIS. It is to be hoped that ventures like the ALIA Research Committee and the initiatives arising from its deliberations will move the profession in Australia, even ever so slowly, towards the recognition that a research culture is an important component of professional presence and continuation. Both CILIP and the ALA have research committees. The Library and Information Research Group is a CILIP special-interest group 'formed in 1977 to bring together those interested in library and information research'; it 'promotes the value of information research and links research with practice' (CILIP, 2007). The ALA has a long-standing interest group in research, the Library Research Round Table: The Library Research Round Table (LRRT) was founded in 1968 to contribute toward the extension and improvement of library 170 The Politics of Libraries and Librarianship research; to provide public program opportunities for describing and evaluating library research projects and for disseminating their findings; to inform and educate ALA members concerning research techniques and their usefulness in obtaining information with which to reach administrative decisions and solve problems; and expand the theoretical base of the field. (ALA, 2007)

If the practical nature of the profession overrules other scholastic achievement, an underlying outcome will be that courses in library studies will eventually lose their place at the university campus, at least in Australia, since it would be argued that there are other institutions where trainees can learn library practice.

\section{What is accreditation worth?}

In basing his model of recognition/accreditation on readiness for professional practice, Parr (1991: 109) states:

when the Association [the LAA] admits a graduate from a recognised school to professional membership it is in effect assuring the community that it has satisfied itself as to that person's professional competence. Of course, that is part of the fiction I referred to... The Association has no way of judging his or her professional competence in the field, it knows only that the applicant has met certain academic criteria.

Is this what the recognition/accreditation process is all about? If so then in order to assure the Australian library community that a graduate from a library school programme was ready for professional practice, ALIA would need to take further steps in its recognition procedures.

Is it time to ask some hard questions.

_ How do we measure a true profession of librarianship?

_ How do we encourage a fruitful nexus between LIS research scholarship and practice?

What is the role of a professional library association in the library education process?

_ How might an association demonstrate its responsibility for standards of entry to a profession?

171

Is library course accreditation a political necessity?

If an association adopts an interest in the education of its future professionals, should that association leave it to the relevant educational institutions to manage educational standards for 
professional preparation?

Should that association monitor or inspect courses?

_ Should reaccreditation be regarded as merely a formality if certain standards are met?

Should the emphasis be on practical preparation?

_ Should there be a recognition of the need to push the intellectual rigour of the discipline?

If there is a board to govern these matters, should its members be elected or appointed using relevant criteria?

Given the politics of education today, should associations

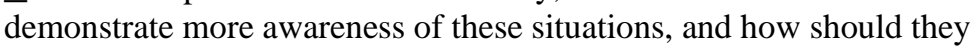
do this?

Are the size and number of LIS schools in a country an issue (see Pawley et al., 2001; Hallam, 2007)?

Parr asked other questions in 1991.

_ Have the library schools delivered on the contract?

- Are they producing graduates capable of performing as professionals

without further training or experience in the field?

Do/should library schools increasingly react to their educational

milieu rather than the professional body?

In 1979 Flowers requested that the nexus between academic

qualification and initial and continuing membership be resolved. Has

this happened?

\section{Conclusion}

Many wiser professionals have gone before the author in discussing the pros and cons of accrediting library programmes. Yet in earlier times in Australia, the stakes were different. Professional associations operated at a time of professional belief and focus, when university education was more stable. They were indeed the 'heady days' of which Flowers (1979) writes.

172

The Politics of Libraries and Librarianship

Today there are a number of issues at play in the complex relationship between LIS professional associations and education for future LIS professionals, particularly in the Australian context. It would be most helpful if our professional purpose was more focused and we regained pride in our professional turf. Instability is a sign of today: instability in the role of the profession, its association(s) and the education for it. How we decide to handle all of these matters and the shifting political nuances that surround LIS education will be a challenge to us all. The accreditation processes outlined in this chapter are based on a serious commitment to education for the profession they serve. This high regard that the profession demonstrates towards the education of its future members is a very important component in a very political process.

\section{Acknowledgements}

An earlier version of this chapter appeared in 2003 as 'Accrediting your library programme: what is it worth?', Singapore Journal of Library and Information Management, 32: 70-82.

\section{Notes}

1. New name for the Library Association of Australia (LAA), adopted in 1989.

2. This issue is a paper in itself. As an example of the 'scholarliness' of the information studies literature, as of October 2007 there were 53 titles listed in the journal citation reports, social science edition, journal summary list on the ISI (2006) Web of Knowledge.

3. The new professional body in the UK formed by the unification of the Institute of Information Scientists (IIS) and the Library Association (LA).

4. Parr (1991: 104) mentions that, at the time of his paper, 'formerly prestigious 
schools have failed ALA re-accreditation as parent universities decline to provide the resources to meet standards'.

5. In outlining some of the political factors, the author has drawn heavily on her own experiences in the knowledge that, as discussed with international colleagues in library education, situations are similar in a number of countries. 6. In 1988 the then federal Minister for Education, John Dawkins, instigated major structural reform of the Australian university system, abolishing the tripartite structure of universities, institutes and colleges and establishing a 'unified national system' of only universities. This reform included a restructuring of the fee structure for university education (Pawley et al., 2001).

7. This situation is Australia-wide (see Pawley et al., 2001).

8. Dare I say, ‘sexy’?

173

Is library course accreditation a political necessity?

\section{References}

ALA (2007) 'Library Research Round Table’; available at: www.ala.org/template .cfm?Section=lrrt (accessed: 9 November 2007).

ALA Committee on Accreditation (2006) AP3: Accreditation Process Policies and Procedures. Chicago, IL: American Library Association.

ALA Office of Accreditation (2007) 'Directory of accredited masters programs'; available at: www.ala.org/ala/accreditation/lisdirb/lisdirectory.htm (accessed: 8 November 2007).

CILIP (2005) 'Accreditation instrument 2005: CILIP’s framework of qualifications enhancing opportunities, rewarding achievement'; available at: www.cilip.org.uk/qualificationschartership/Wheretostudy/Accreditation+Inst rument.htm (accessed: 9 November 2007).

CILIP (2007) 'Library and Information Research Group'; available at: www.cilip .org.uk/specialinterestgroups/bysubject/research/ (accessed: 9 November 2007). Department of Education, Science \& Training (DEST) (2007a) 'Going to uni: higher education for students in Australia'; available at: www.goingtouni.gov .au/ (accessed: 9 November 2007).

Department of Education, Science \& Training (DEST) (2007b) 'Research quality framework: assessing the quality and impact of research in Australia'; available at: www.dest.gov.au/sectors/research_sector/policies_issues_reviews/ key_issues/research_quality_framework/default.htm (accessed: 9 November 2007). Flowers, E. (1979) 'The getting of wisdom... or all you ever wanted to know about LAA course recognition', Australian Library Journal, October: 316-24. Hallam, G. (2005) 'Truly a profession: reflective and research-focused', inCite, December: 4-5.

Hallam, G. (2007) 'Education for library and information service', in S. Ferguson (ed.) Libraries in the Twenty-first Century: Charting New Directions in Information Services. Wagga Wagga, NSW: Centre for Information Studies, pp. 311-36.

IFLA (2000) 'Guidelines for professional library/information educational programs - 2000’; available at: www.ifla.org/VII/s23/bulletin/guidelines.htm (accessed: 5 September 2007).

ISI (2006) 'Web of knowledge: journal citation results: information and library science'; available at: http://portal.isiknowledge.com.dbgw.lis.curtin.edu.au/ portal.cgi (accessed: 31 October 2007).

Parr, E. (1991) 'Course recognition: a new approach for a new association', Australian Library Journal, May: 98-111.

Pawley, C., Willard, P. and Wilson, C.S. (2001) 'Trends and transformations: the changing face of library and information studies in Australia', Journal of Education for Library and Information Science, 42(4): 325-38.

Riss-Fang, J., Stueart, R.D. and Tuamsuk, K. (eds) (1995) World Guide to Library Archive and Information Science Education, 2nd edn. Munich: KG Saur/IFLA.

Smith, K. (2003) 'Performance measurement of Australian geoscientific minerals researchers in the changing funding regimes', $\mathrm{PhD}$ thesis, Murdoch

University; available at: http://wwwlib.murdoch.edu.au/adt/browse/list/S-Z (accessed: 8 November 2007).

174

The Politics of Libraries and Librarianship

Smith, K. and Harvey, R. (2006) 'Is there a role for professional associations in fostering research', in C. Khoo, D. Singh and A.S. Chaudhry (eds) Proceedings of the Asia-Pacific Conference on Library \& Information Education \& Practice 
2006. Singapore: Division of Information Studies, School of Communication \& Information, Nanyang Technological University, pp. 612-19.

The Shorter Oxford English Dictionary on Historical Principles (1984) 3rd edn. Oxford: Oxford University Press.

World List of Departments and Schools of Information Studies, Information Management, Information Systems, etc. (2007) available at: http://informationr .net/wl/ (accessed: 8 November 2007).

\section{Further reading}

Australian Library and Information Association (2001) 'Vale Board of Education', inCite, September: 22.

Australian Library and Information Association (1998, 2005) 'Core knowledge, skills and attributes'; available at: www.alia.org.au/policies/core.knowledge.html (accessed: 9 November 2007).

Australian Library and Information Association (2005) 'ALIA's role in education of library and information professionals'; available at: $w w w$. alia.org.au/ policies/education.role.html (accessed: 9 November 2007).

Australian Library and Information Association (2007) 'The ALIA research and exchange partnertship’; available at: www.alia.org.au/research/ (accessed: 9 November 2007).

CILIP (2004) 'Body of professional knowledge'; available at: www.cilip.org .uk/qualificationschartership/bpk (accessed: 9 November 2007).

CILIP (2007) 'Courses in library and information studies currently accredited by CILIP’; available at: www.cilip.org.uk/qualificationschartership/Wheretostudy (accessed: 9 November 2007).

CILIP (2007) ‘Qualifications and chartership’; available at: www.cilip.org.uk qualificationschartership/ (accessed: 9 November 2007).

Hallam, G. (2006) ‘The changing face of LIS education', inCite, April: 4.

Martin, W. (1999) 'New directions in education for LIS: knowledge management programs at RMIT', Journal of Education for Library and Information Science, 40(3): 142-50.

Nimon, M. (2002) 'Stepping into the future: changes in LIS education at University of South Australia', inCite, October: 22.

Willard, P., Wilson, C.S. and Pawley, C. (2001) 'Australian professional library and information education: structural changes in the 1990s', Australian Academic and Research Libraries, 32(4): 294-307.

175

Is library course accreditation a political necessity? 